\title{
ANALYSIS OF POLYMORPHISMS AT THE ADIPONECTIN GENE LOCUS IN ASSOCIATION WITH TYPE 2 DIABETES, BODY MASS INDEX AND CARDIOVASCULAR TRAITS IN LATVIAN POPULATION
}

\author{
Ineta Kalnina*, Gustavs Latkovskis**, Liene Nikitina-Zake*, Vitolds Mackevičs***, \\ Raitis Pečulis*, Ivo Kāpa*, Dāvids Fridmanis* ${ }^{*}$ Andrejs Ërglis ${ }^{\star * *}$, Valdis Pīrāgs ${ }^{* \star * *}$, \\ and Jānis Klovin, $\check{c}^{*}$

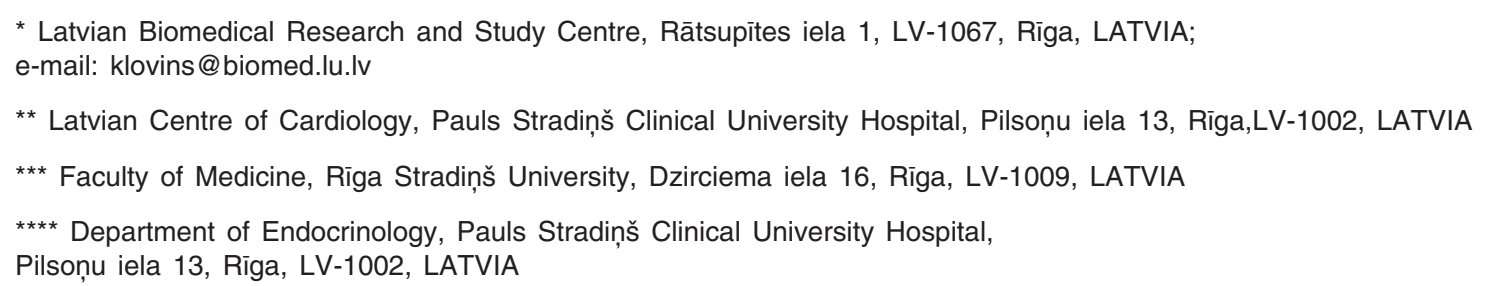

Communicated by Ludmila Vīksna

\begin{abstract}
Despite the number of recently conducted studies seeking to determine the association between genetic variants of adiponectin gene and susceptibility to type 2 diabetes (T2D) and increased body mass index (BMI), the results obtained are often inconsistent. To determine the impact of common polymorphisms in promoter and coding regions of adiponectin gene on these conditions in Latvian population, we selected ten SNPs (rs2241767, rs1501299, rs3777261, rs16861210, rs2241766, rs822396, rs182052, rs17300539, rs16861194, rs266729) based on haploblock structure and previously reported association studies. The selected SNPs were screened in a study group of 835 participants from the Genome Data Base of Latvian Population and mainly consisted of patients with T2D and coronary heart disease. None of the individual polymorphisms were significantly associated with T2D status or BMI when analysed using logistic or linear regression and adjusted for gender, age and other significant covariates. Frequency of rs2241766 T allele homozygotes however was significantly increased in T2D patients compared to controls (uncorrected $\mathrm{P}=0.007$ ). When analysed with other traits, the rs $182052 \mathrm{G}$ allele was found to be less frequent in patients suffering from myocardial infarction $(\mathrm{P}=0.02 ; \mathrm{O}=0.76, \mathrm{Cl}=5 \%$ [0.61-0.92]) compared to others. Haplotype analysis revealed significant association of one haplotype with atrial fibrillation (uncorrected $\mathrm{P}=0.01$ ). In summary, we conclude that SNPs in adiponectin gene are unlikely to represent the risk for T2D, but may be involved in pathogenesis of $\mathrm{CHD}$ in the Latvian population.
\end{abstract}

Key words: $A D I P O Q$, tagSNP, BMI, T2D, CHD.

\section{INTRODUCTION}

Adiponectin is an adipose tissue-derived plasma protein that plays an important role in energy homeostasis regulation, glucose and lipid metabolism as well as anti-inflammatory responses in the vascular system (Hu et al., 1996; Ouchi et al., 2003). Low plasma adiponectin concentrations are linked to type 2 diabetes (T2D) (Weyer et al., 2001), obesity (Matsuzawa et al., 2003) and coronary heart disease (CHD) related traits ( Matsuda et al., 2002; Kumada et al., 2003). Possible mechanisms of adiponectin action in relation with these inflammatory diseases may include its inhibition of smooth muscle cell proliferation, monocyte adhe- sion to endothelium, and macrophage uptake of LDL (Chen et al., 2005).

Adiponectin is a product of the $A D I P O Q$ gene consisting of three exons that occupies $16 \mathrm{~kb}$ on chromosome $3 \mathrm{q} 27$. During the last five years, a large number of association studies have been performed to search for polymorphisms that may influence metabolic conditions (reviewed in Vasseur et al. (2006) and Menzaghi et al. (2007)). Even though the number of polymorphisms and haplotypes are repeatedly associated with increased or decreased blood adiponectin levels (Heid et al., 2006; Mackevics et al., 2006; Li et al., 2007; Kyriakou et al., 2008), association analysis of these SNPs 
with metabolic and cardiovascular phenotypes give inconsistent results across different studies.

The aim of our study was to search for the association between systematically selected adiponectin gene polymorphisms and T2D, body mass index (BMI) as well as CHD phenotypes in the Latvian population.

\section{MATERIALS AND METHODS}

Study subjects. The study was based on data and samples from the Genome Data Base of Latvian Population, the disease based biobank. Briefly: participating individuals were over the age of 18; the health status was recorded, the diagnoses were based on approved clinical criteria according to the ICD-10 codes (International Classification of Diseases); andanthropometric measurements (including weight and stature), ethnic, social, environmental information and familial health status was acquired based on a self-reported questionnaire. Written informed consent was obtained from all participants. The study group for the subsequent genotyping of selected markers was selected from all available subjects with validated health records and questionnaires in the biobank. We excluded patients with diseases where outcome or treatment may influence BMI, including all types of cancer and diseases of the thyroid gland, but not excluding patients with cardiovascular diseases. All patients with T2D were included in the study. In total, 835 subjects were selected based on these criteria. The study protocol was approved by the Central Medical Ethics Committee of Latvia.

SNP genotyping. TagSNPs in the adiponectin gene locus were selected using Haploview software (Barrett et al., 2005). The SNPs with previously published effect on adiponectin plasma concentration were force included in the tagSNP set. MALDI TOF-based genotyping platform (Bruker Daltonics) was used for genotyping all SNPs (primer sequences and reaction conditions available upon request). Genotype calling and quality control was performed using GenoTools software (Bruker Daltonics).

Statistical analysis. Statistical analyses were performed with the PLINK 1.06 software (http://pngu.mgh.harvard.edu/purcell/plink/) (Purcell et al., 2007). In contrast to the natural BMI values, the logarithmically transformed BMI values displayed normal distribution and were further used for all quantitative analyses. Linear regression was applied to examine the association between tagSNPs and log-BMI adjusting for age and gender. The allelic association test (additive model), dominant and recessive model analysis was performed using the exact Fisher's test. Logistic regression analysis adjusting for age and those factors that showed significant association with trait under multivariate logistic regression analysis were used for dichotomous trait analysis. Bonferroni correction was used to adjust for multiple testing. The permutation test was performed using label-swapping between SNP and trait condition or $\log \mathrm{BMI}$ values but leaving intact correlation with other covariates. 10,000 permutations were performed for each analysis and corrected (EMP2) $P$-values were used. These values are corrected based on calculation of the proportion of permutations in which any of the test statistics exceeds the particular observed statistic and are more stringent then uncorrected $P$-values. Odds ratios (OR) and CI $(95 \%)$ values were obtained from logistic regression analysis $(\operatorname{Exp}(B)$ value), unadjusted mean $\log B$ MI values were calculated and back-transformed for each genotype.

\section{RESULTS}

Description of the study group is summarised in Table 1. A total of ten SNPs in the adiponectin gene locus were genotyped in all or part of the participants. SNP information, observed minor allele frequency (MAF) and results of deviation from the Hardy-Weinberg equilibrium test are shown in Table 2. None of the SNPs were in disagreement with Hardy-Weinberg equilibrium after correction for multiple testing. The exact number of successfully genotyped samples for each SNP in the study group is displayed in Tables 3 and 4, along with the results of association with T2D and $\operatorname{logBMI}$ values, respectively. The SNP rs2241766 was asso-

Table 1

CHARACTERISTICS OF THE STUDY POPULATION

\begin{tabular}{ll}
\hline \multicolumn{1}{c|}{ Parameter } & \multicolumn{1}{c}{ Values } \\
\hline Total number of patients & 835 \\
Percentage of females (n) & $66.7(557)$ \\
Percentage of males (n) & $33.3(278)$ \\
Percentage of patients (n) with: & \\
Type 2 diabetes & $20.3(170)$ \\
Hypertension & $55.9(467)$ \\
Heart failure & $52.2(435)$ \\
Atrial fibrillation & $4.6(39)$ \\
Myocardial infarction & $46.2(390)$ \\
Age (years) [mean \pm SD] & $62.82 \pm 10.12$ \\
BMI [mean \pm SD] & $28.77 \pm 4.71$
\end{tabular}

Table 2

CHARACTERISTICS OF TEN SNPS GENOTYPED IN 835 SUBJECTS

\begin{tabular}{c|c|c|c|c|c|c|c}
\hline $\begin{array}{c}\text { SNP } \\
\text { No. }\end{array}$ & rs code & $\begin{array}{c}\text { Genome } \\
\text { position }\end{array}$ & $\begin{array}{c}\text { Gene posi- } \\
\text { tion }\end{array}$ & $\begin{array}{c}\text { Com- } \\
\text { mon } \\
\text { allele }\end{array}$ & $\begin{array}{c}\text { Rare } \\
\text { allele }\end{array}$ & MAF & $\begin{array}{c}\text { H-W test } \\
P \text { value }\end{array}$ \\
\hline 1 & rs16861194 & 188042119 & -11422 & A & G & 0.12 & 0.29 \\
2 & rs17300539 & 188042154 & -11387 & G & A & 0.05 & 0.11 \\
3 & rs266729 & 188042168 & -11373 & C & G & 0.28 & 0.01 \\
4 & rs182052 & 188043476 & -10065 & G & A & 0.43 & 0.35 \\
5 & rs16861210 & 188049192 & -4349 & G & A & 0.05 & 0.27 \\
6 & rs822396 & 188049571 & -3970 & A & G & 0.22 & 1 \\
7 & rs2241766 & 188053586 & 45 & T & G & 0.05 & 0.66 \\
8 & rs1501299 & 188053817 & 276 & A & C & 0.28 & 1 \\
9 & rs2241767 & 188053890 & 349 & A & G & 0.05 & 1 \\
10 & rs3774261 & 188054253 & 712 & G & A & 0.33 & 0.93
\end{tabular}

MAF, minor allele frequency; H-W, Hardy-Weinberg equilibrium

a - according to the NCBI build $36 ;^{\mathbf{b}}$ - relating to the first position of the starting codon ATG 
ASSOCIATION OF T2D WITH TEN tagSNPs

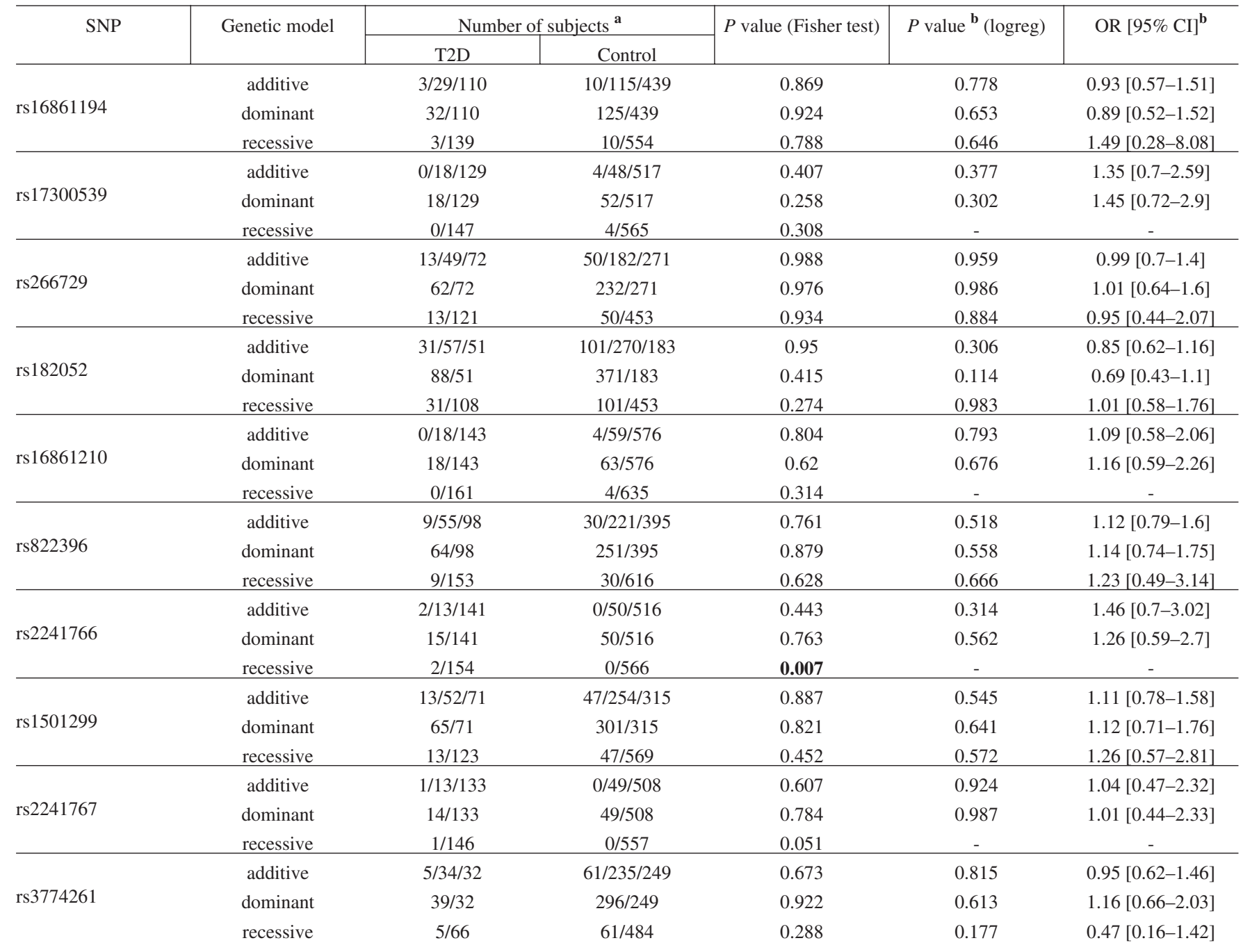

Logreg- logistic regression;

a- Distribution of subjects according to genotypes/models: additive 22/12/11; dominant: 12+22/11; recessive 22/12+11 (1, common allele; 2, rare allele)

b- From logistic regression analysis adjusted for gender, age and logBMI

ciated with T2D under the recessive model $(P=0.007)$. This association remained significant after applying the permutation test $(P=0.049)$, but lost its significance after correction for multiple comparisons. Neither of the SNPs showed any association with T2D when tested using logistic regression with adjustment for age, sex and BMI under different genetic models (Table 3). Similarly, no difference in mean values of $\log$ BMI was found between genotypes of any SNP included in analysis (Table 4). We also tested for association of SNPs with other traits present in our study group. The results are shown in Figure 1A. Allele A of SNP rs182052 was less frequent in patients with myocardial infarction $(39 \%)$ compared to controls (45\%). This association remained significant using multiple logistic regression analysis adjusting for sex, age, BMI and T2D $(P=0.02$; OR $=0.76$, CI95\%[0.61-0.92]). The permutation test on this SNP gave a corrected $P$ value of 0.028 . The association did not retain its significance after Bonferroni correction.
In order to identify possible effects of individual haplotypes on traits analysed in our study we performed haplotypebased association. In total, 14 haplotypes were reconstructed with frequency exceeding $1 \%$. Statistical analysis of the distribution of probabilistically-inferred set of haplotypes for different traits is shown in Figure 1B. Haplotype determined by C and A alleles of rs1501299 and rs3774261, respectively, and common alleles for other SNPs was more frequent $(26 \%)$ in patients with atrial fibrillation compared to others $(14 \%), P=0.009$.

\section{DISCUSSION}

We report in this study the first evaluation of adiponectin gene polymorphisms in relation with T2D, BMI and cardiovascular traits in the Latvian population. First we performed systematic selection of tagSNPs in $A D I P O Q$ gene locus in 
ASSOCIATION OF BMI WITH TEN tagSNPs

\begin{tabular}{|c|c|c|c|c|c|c|c|}
\hline \multirow[t]{2}{*}{ SNP } & \multirow{2}{*}{\begin{tabular}{|c|} 
Number of subjects \\
$11 / 12 / 22$ \\
\end{tabular}} & \multicolumn{3}{|c|}{ Mean $[ \pm \mathrm{SE}] \mathrm{BMI}^{\mathrm{a}}$} & \multicolumn{3}{|c|}{$P$ value ${ }^{\mathbf{b}}$} \\
\hline & & 11 & 12 & 22 & Additive & Dominant & Recessive \\
\hline rs16861194 & $539 / 143 / 13$ & $29.47[0.23]$ & $29.84[0.39]$ & $30.23[1.23]$ & 0.244 & 0.266 & 0.536 \\
\hline rs266729 & $340 / 227 / 60$ & $29.79[0.28]$ & $29.59[0.32]$ & 29.58 [0.59] & 0.427 & 0.447 & 0.615 \\
\hline rs182052 & $232 / 320 / 131$ & $29.48[0.32]$ & $29.57[0.29]$ & $30.28[0.41]$ & 0.094 & 0.358 & 0.053 \\
\hline rs16861210 & $706 / 77 / 4$ & $29.65[0.21]$ & $29.71[0.52]$ & $30.61[2.24]$ & 0.737 & 0.757 & 0.825 \\
\hline rs822396 & $487 / 270 / 38$ & $29.71[0.24]$ & $29.54[0.3]$ & $29.45[0.73]$ & 0.436 & 0.455 & 0.670 \\
\hline rs 2241766 & $647 / 62 / 2$ & $29.62[0.21]$ & $29.85[0.58]$ & $33.15[3.14]$ & 0.373 & 0.510 & 0.137 \\
\hline rs1501299 & $379 / 302 / 60$ & $29.82[0.26]$ & $29.81[0.3]$ & $29.47[0.58]$ & 0.696 & 0.700 & 0.836 \\
\hline rs 2241767 & $631 / 61 / 1$ & $29.59[0.22]$ & $30.63[0.57]$ & $34.78[4.4]$ & 0.110 & 0.137 & 0.256 \\
\hline rs3777261 & $276 / 265 / 66$ & $29.68[0.34]$ & $29.3[0.35]$ & $30.09[0.59]$ & 0.926 & 0.628 & 0.328 \\
\hline
\end{tabular}

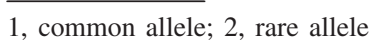

a- BMI values back-transformed from unadjusted mean $\operatorname{logBMI}$ values

b- $P$ values from linear regression analysis adjusted for gender and age
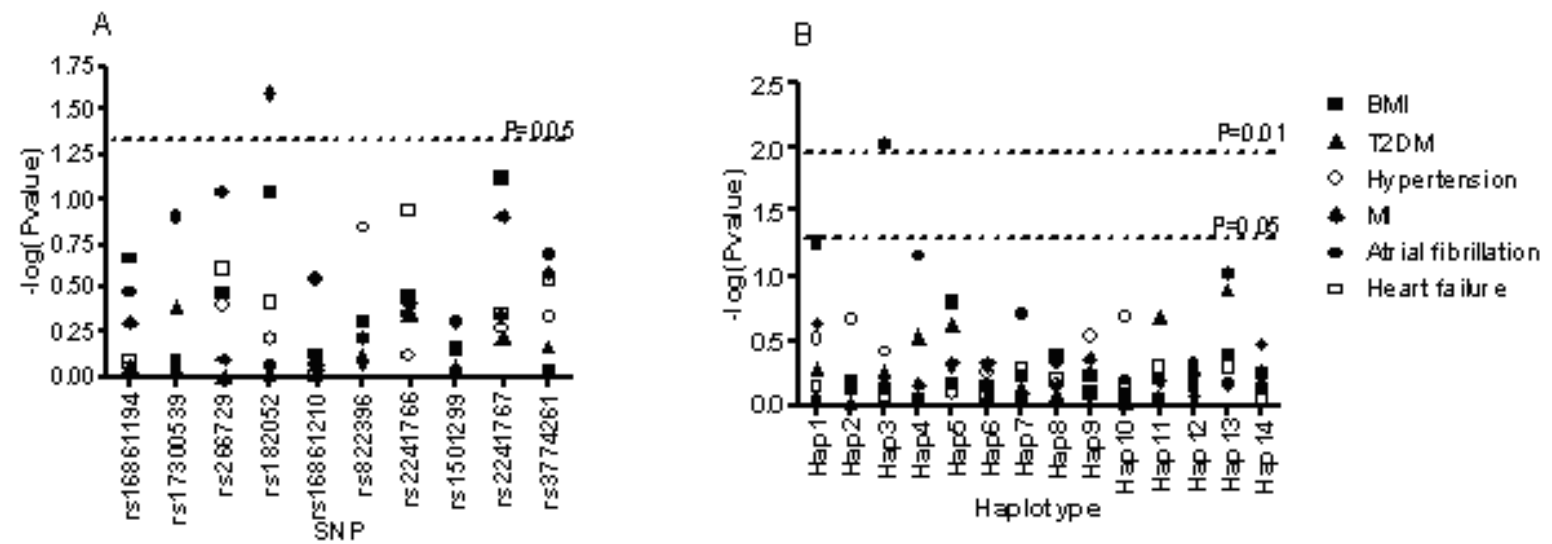

Fig. 1. Significance values depicted as negative logarithm of $P$ value from adjusted linear or logistic regression analysis for SNP (A) and haplotype (B) association with all phenotypes.

order to ensure maximal capture of all known alleles. In addition, the forced inclusion of variants shown to influence plasma adiponectin levels was performed. Estimated minor allele frequencies (Table 2) of all ten SNPs were higher than 0.05 in the Latvian population and similar to those reported in the SNP database (www.ncbi.nlm.nih.gov/SNP) or other publications (Heid et al., 2006). We believe that altogether this ensures the high informativeness of the selected set of ten markers.

In the present quantitative trait analysis we found no evidence for an association of the tested SNPs with changes in BMI value. Other studies have previously reported that at least three of the SNPs also included in this study (rs266729, rs2241766, rs1501299) might modulate body weight (reviewed in Vasseur et al. (2006)). However, recent meta-analysis did not confirm the association of these or other markers with BMI (Menzaghi et al., 2007). The failure to identify a stable association between $A D I P O Q$ polymorphisms and BMI, despite the repeatedly confirmed rela- tionship between the levels of plasma adiponectin and BMI (Yang et al., 2001; Spranger et al., 2003), can be explained by the variation in genetic background determining the predisposition to obesity. Stratification of the study group based on common genetic variants influencing body mass regulation could help to estimate the role of adiponectin SNPs more precisely.

The only SNP that was significantly associated with T2D in our study was rs2241766, under the recessive genetic model. The relatively low frequency of this SNP and absence of GG homozygotes in the control group, however, do not allow to precisely determine the relative risk of this variation. $\mathrm{G}$ allele of rs2241766 was found to be associated with decreased levels of serum adiponectin (Xita et al., 2005; Li et al., 2007;) as well as T2D (Li et al., 2007). This result is in agreement with finding, that low plasma levels are associated with insulin resistance and T2D. It should be noted, however, that a substantial number of studies failed to replicate these results (Mackevics et al., 2006; Potapov et 
al., 2008; Szopa et al., 2009). Since previous studies did not support the recessive model for association of rs2241766 with T2D our result may be as well a false positive finding.

Adiponectin mediates vascular inflammation as an inhibitor of smooth muscle cell proliferation and macrophage uptake and has been associated with decreased risk of hypertension (Iwashima et al., 2004), miocardial infarction (Pischon et al., 2004) and ischemic stroke (Chen et al., 2005). We, therefore, tested the association of all SNPs analysed with presence of different cardiovascular traits. In our study, rs182052 was associated with decreased risk of miocardial infarction. Allele A of rs182052 was previously associated with a decreased adiponectin serum level (Heid et al., 2006; Kyriakou et al., 2008) and, thus, would be expected to have negative effect on cardiovascular functions which is opposite to our finding. Nevertheless, Hegener et al. (2006) reported a decreased risk of ischemic stroke for carriers of this allele. One of the imputed haplotypes was found to be more frequent in another heart disease trait, atrial fibrillation. To our knowledge this is the first report of genetic variants of adiponectin associated with this trait. The two SNPs, rs1501299 and rs3774261, determining this haplotype, have been associated with increased adiponectin level (Heid et al., 2006; Kyriakou et al., 2008). Interestingly, plasma adiponectin is higher in patients with persistent atrial fibrillation (Shimano et al., 2008), which is in opposite to the general tendency of a high adiponectin level being protective to most of the CHD-related pathogeneses. Similarly, high blood adiponectin was found to be a predictor for mortality in heart failure (Chang et al., 2009). It has been speculated that this could be explained with lower sensitivity of adiponectin receptors in atrial fibrillation resulting in increased adiponectin secretion (Shimano et al., 2008). In general, however, the situation with CHD and adiponectin polymorphisms is similar to obesity and T2D, where associations found in some studies can not be consistently replicated in other studies (Menzaghi et al., 2007; Vasseur et al., 2006). It should also be mentioned that none of the genome wide association studies have identified the $A D I P O Q$ locus as a candidate for any trait (based on a database search at https://gwas.lifesciencedb.jp and http://www.genome.gov/gwastudies/).

The main drawback of our study is an increased proportion of patients with metabolic and cardiovascular traits in study group. The relatively low number of healthy participants in the study may have increased Type II error, which would mask some existing association or decrease the statistical power. From this respect, additional study with a large control group is needed to fully evaluate the impact of adiponectin polymorphisms on T2D and BMI in the Latvian population. An important problem in all studies on a large number of genetic variations is multiple testing. In our study, none of the discovered associations retained its significance $(P<0.05)$ after applying the Bonferroni test. It has been suggested, however, that study-wide adjustments are not appropriate in the context of genetic association analysis and that permutation based significance testing can be used instead. All associations found in this study remained significant after the permutation test.

In summary, although adiponectin plasma levels are linked with many metabolic traits, our study does not provide strong support for the hypothesis that SNPs in the ADIPOQ locus play an important role in development of T2D, obesity and CHD.

\section{ACKNOWLEDGEMENTS}

The work was supported by the National Research Programme in Medicine 2006-2009 project No. 14, "Creation of the unified and generally accessible data base on the main life expectancy and life quality threatening pathologies and epidemiology of their risk factors in Latvian population”, Latvian Council of Science Grant 01.0023.01. We acknowledge Genome Database of Latvian Population, Latvian Biomedical Research and Study Centre for providing data and DNA samples.

\section{REFERENCES}

Barrett, J.C., Fry, B., Maller, J., Daly, M.J. (2005). Haploview: Analysis and visualization of LD and haplotype maps. Bioinformatics, 21, 263-265.

Chang, L.C., Huang, K.C., Wu, Y.W., Kao, H.L., Chen, C.L., Lai, L.P., Hwang, J.J., Yang, W.S. (2009). The clinical implications of blood adiponectin in cardiometabolic disorders. J. Formos. Med. Assoc., 108, 353-366.

Chen, M.P., Tsai, J.C., Chung, F.M., Yang, S.S., Hsing, L.L., Shin, S.J., Lee, Y.J. (2005). Hypoadiponectinemia is associated with ischemic cerebrovascular disease. Arterioscler. Thromb. Vasc. Biol., 25, 821-826.

Hegener, H.H., Lee, I.M., Cook, N.R., Ridker, P.M., Zee, R.Y. (2006). Association of adiponectin gene variations with risk of incident myocardial infarction and ischemic stroke: A nested case-control study. Clin. Chem., 52, 2021-2027.

Heid, I.M., Wagner, S.A., Gohlke, H., Iglseder, B., Mueller, J.C., Cip, P., Ladurner, G., Reiter, R., Stadlmayr, A., Mackevics, V., Illig, T., Kronenberg, F., Paulweber, B. (2006). Genetic architecture of the APMI gene and its influence on adiponectin plasma levels and parameters of the metabolic syndrome in 1,727 healthy Caucasians. Diabetes, 55, 375-384.

Hu, E., Liang, P., Spiegelman, B.M. (1996). AdipoQ is a novel adipose- specific gene dysregulated in obesity. J. Biol. Chem., 271, 10697-10703.

Iwashima, Y., Katsuya, T., Ishikawa, K., Ouchi, N., Ohishi, M., Sugimoto, K., Fu, Y., Motone, M., Yamamoto, K., Matsuo, A., Ohashi, K., Kihara, S., Funahashi, T., Rakugi, H., Matsuzawa, Y., Ogihara, T. (2004). Hypoadiponectinemia is an independent risk factor for hypertension. Hypertension, 43, 1318-1323.

Kumada, M., Kihara, S., Sumitsuji, S., Kawamoto, T., Matsumoto, S., Ouchi, N., Arita, Y., Okamoto, Y., Shimomura, I., Hiraoka, H., Nakamura, T., Funahashi, T., Matsuzawa, Y. (2003). Association of hypoadiponectinemia with coronary artery disease in men. Arterioscler. Thromb. Vasc. Biol., 23, 85-89.

Kyriakou, T., Collins, L.J., Spencer-Jones, N.J., Malcolm, C., Wang, X., Snieder, H., Swaminathan, R., Burling, K.A., Hart, D.J., Spector, T.D., O'Dell, S.D. (2008). Adiponectin gene ADIPOQ SNP associations with serum adiponectin in two female populations and effects of SNPs on promoter activity. J. Hum. Genet., 53, 718-727.

Li, L.L., Kang, X.L., Ran, X.J., Wang, Y., Wang, C.H., Huang, L., Ren, J., Luo, X., Mao, X.M. (2007). Associations between 45T/G polymorphism of the adiponectin gene and plasma adiponectin levels with type 2 diabetes. Clin. Exp. Pharmacol. Physiol., 34, 1287-1290. 
Mackevics, V., Heid, I.M., Wagner, S.A., Cip, P., Doppelmayr, H., Lejnieks, A., Gohlke, H., Ladurner, G., Illig, T., Iglseder, B., Kronenberg, F., Paulweber, B. (2006). The adiponectin gene is associated with adiponectin levels but not with characteristics of the insulin resistance syndrome in healthy Caucasians. Eur. J. Hum. Genet., 14, 349-356.

Matsuda, M., Shimomura, I., Sata, M., Arita, Y., Nishida, M., Maeda, N., Kumada, M., Okamoto, Y., Nagaretani, H., Nishizawa, H., Kishida, K., Komuro, R., Ouchi, N., Kihara, S., Nagai, R., Funahashi, T., Matsuzawa, Y. (2002). Role of adiponectin in preventing vascular stenosis. The missing link of adipo-vascular axis. J. Biol. Chem., 277, 37487-37491.

Matsuzawa, Y., Shimomura, I., Kihara, S., Funahashi, T. (2003). Importance of adipocytokines in obesity-related diseases. Horm. Res., 60 (Suppl 3), 56-59.

Menzaghi, C., Trischitta, V., Doria, A. (2007). Genetic influences of adiponectin on insulin resistance, type 2 diabetes, and cardiovascular disease. Diabetes, 56, 1198-1209.

Ouchi, N., Kihara, S., Funahashi, T., Matsuzawa, Y., Walsh, K. (2003). Obesity, adiponectin and vascular inflammatory disease. Curr. Opin. Lipidol., 14, 561-566

Pischon, T., Girman, C.J., Hotamisligil, G.S., Rifai, N., Hu, F.B., Rimm, E.B. (2004). Plasma adiponectin levels and risk of myocardial infarction in men. JAMA, 291, 1730-1737.

Potapov, V.A., Chistiakov, D.A., Dubinina, A., Shamkhalova, M.S., Shestakova, M.V., Nosikov, V.V. (2008). Adiponectin and adiponectin receptor gene variants in relation to type 2 diabetes and insulin resistance-related phenotypes. Rev. Diabet. Stud., 5, 28-37.
Purcell, S., Neale, B., Todd-Brown, K., Thomas, L., Ferreira, M.A., Bender, D., Maller, J., Sklar, P., de Bakker, P.I., Daly, M.J., Sham, P.C. (2007). PLINK: A tool set for whole-genome association and population-based linkage analyses. Amer. J. Hum. Genet., 81, 559-575.

Shimano, M., Shibata, R., Tsuji, Y., Kamiya, H., Uchikawa, T., Harata, S., Muto, M., Ouchi, N., Inden, Y., Murohara, T. (200). Circulating adiponectin levels in patients with atrial fibrillation. Circ. J., 72, 1120-1124.

Spranger, J., Kroke, A., Mohlig, M., Bergmann, M.M., Ristow, M., Boeing, H., Pfeiffer, A.F. (2003). Adiponectin and protection against type 2 diabetes mellitus. Lancet, 361, 226-228.

Szopa, M., Malczewska-Malec, M., Wilk, B., Skupien, J., Wolkow, P., Malecki, M.T., Sieradzki, J. (2009). Variants of the adiponectin gene and type 2 diabetes in a Polish population. Acta Diabetol., January.

Vasseur, F., Meyre, D., Froguel, P. (2006). Adiponectin, type 2 diabetes and the metabolic syndrome: Lessons from human genetic studies. Expert Rev. Mol. Med., 8, 1-12.

Weyer, C., Funahashi, T., Tanaka, S., Hotta, K., Matsuzawa, Y., Pratley, R.E., Tataranni, P.A. (2001). Hypoadiponectinemia in obesity and type 2 diabetes: Close association with insulin resistance and hyperinsulinemia. $J$. Clin. Endocrinol. Metab., 86, 1930-1935.

Xita, N., Georgiou, I., Chatzikyriakidou, A., Vounatsou, M., Papassotiriou, G.P., Papassotiriou, I., Tsatsoulis, A. (2005). Effect of adiponectin gene polymorphisms on circulating adiponectin and insulin resistance indexes in women with polycystic ovary syndrome. Clin. Chem., 51, 416-423.

Yang, W.S., Lee, W.J., Funahashi, T., Tanaka, S., Matsuzawa, Y., Chao, C.L., Chen, C.L., Tai, T.Y., Chuang, L.M. (2001). Weight reduction increases plasma levels of an adipose-derived anti-inflammatory protein, adiponectin. J. Clin. Endocrinol. Metab., 86, 3815-3819.

Received 11 July 2009

\section{ADIPONEKTĪNA GĒNA LOKUSA ASOCIĀCIJAS ANALĪZE SAISTĪBĀ AR OTRĀ TIPA DIABĒTU, K⿻ERMEN,A MASAS INDEKSU UN KARDIOVASKULĀRĀM PAZİMĒM LATVIJAS POPULĀCIJĀ}

Neraugoties uz daudzajiem adiponektīna gēna variantu asociācijas pētījumiem saistībā ar otrā tipa diabētu (T2D) un paaugstinātu ḳermeṇa masas indeksu (K,MI), līdz šim iegūtie rezultāti bieži ir pretrunīgi. Lai noskaidrotu adiponektīna gēna promotera un kodējošā rajona bieži sastopamo polimorfismu ietekmi uz šìm pazīmēm Latvijas populācijā, balstoties uz haplobloku struktūru un iepriekš zināmiem asociācijas pētîjumiem, tika izvēelēti desmit SNP (rs2241767, rs1501299, rs3777261, rs16861210, rs2241766, rs822396, rs182052, rs17300539, rs16861194, rs266729). Izvēlētie SNP tika genotipēti pētījuma grupā, kas sastāvēja no 835 Valsts iedzìvotāju genoma datu bāzes gēnu donoriem. Šajā grupā bija pārsvarā no T2D un koronārās sirds slimības (KSS) pacienti. Neviens no individuāliem polimorfismiem nebija būtiski asociēts ar T2D vai KMI, lietojot daudzfaktoru loǵistiskās vai lineārās regresijas analīzes un koriǵējot rezultātus pēc dzimuma, vecuma un citiem būtiskiem līdzfaktoriem. Tomēr tika atrasts, ka rs2241766 T alēles homozigotu frekvence T2D pacientu vidū bija būtiski lielāka nekā kontroles grupā (nekorig̣ēta $P=0.007$ ). Analizējot saistībā ar citām pazīmēm, rs182052 G alēle tika biežāk atrasta pacientiem ar miokarda infarktu $(P=0.02$; OR $=0.76$; CI95\%[0.61-0.92]), salīdzinot ar pārējo pētījuma grupu. Haplotipu analīze atklāja viena haplotipa būtisku asociāciju ar mirdzaritmiju (nekoriǵēta $P=0.01$ ). Kopumā var secināt, ka adiponektīna gēna polimorfismi nav uzskatāmi par būtiskiem T2D riska faktoriem, bet varētu būt iesaistīti koronārās sirds slimības patoǵenēzē Latvijas populācijā. 